\title{
Activation of the Role of Tetrahelix to Strengthen Students' Awareness in Learning During Pandemic
}

\author{
Rahmat Rahmat ${ }^{1 *}$, Sapriya Sapriya ${ }^{2}$, Sri Wahyuni ${ }^{3}$ \\ 1,2,3 Universitas Pendidikan Indonesia, Indonesia \\ *Corresponding author. Email: rahmat@upi.edu
}

\begin{abstract}
Online learning. is one of the educational transformations during the pandemic as an effort to narrow the spread and transmission of the Covid-19 virus. However, the consequences of changes without the readiness of various parties, have led to the emergence of an educational crisis that has an impact on the decline in the quality of graduates, one of which is student awareness in learning. This is the background for conducting this research with the aim of knowing how to activate the role of Tetrahelix in strengthening students' awareness of learning during a pandemic. This research was conducted using a mixed methods design, with a parallel convergent method. The research data were collected through interviews, observations, documentation, questionnaires, and literature studies, which were carried out according to health protocol standards set by the government. The subjects in this study were the Civitas SMPN 2 Bandung which consisted of: students, teachers and principals, parents, and the committee/community. The results of this study are: (1) caring character education is reflected in three learning activities, namely conditioning, modeling, and habituation; (2) Activating the role of Tetrahelix (parents, teachers, committees and school officials) has an impact on value-conscious learning that encourages strengthening student awareness; (3) efforts to activate a collaborative role are: analyzing problems, equating goals, confirming who does what, analyzing carrying capacity, and determining the technical characteristics of caring character-based learning.
\end{abstract}

Keywords: Activation, Tetrahelix. Student Awareness

\section{INTRODUCTION}

The COVID-19 pandemic has changed many things, including in the field of education. The condition of changing traditional education patterns to technology-based education or what is known as online is currently being carried out in full. This education transformation policy is nothing but one of the government's strategic efforts in narrowing the spread and transmission of the Covid-19 virus. Thuslearning online will massively affect psychological conditions which also have an impact on student character development. Character is a visual image of a human being that is unique and different from other people as a whole. According to Muslich [1] character is a form of the overall thoughts, feelings, and behavior of humans themselves. So the balance between these three parts will create an ideal character shape.

Seeing the situation on the ground, talking about the character of students certainly cannot be separated from being vulnerable to school age, in such vulnerable times they tend to make photocopies of their parents. In the view of parents, the behavior of parents certainly has a big enough role for children. When they show empathy for Covid-19 victims, teach health protocols, of course children will follow the example. Reported from mediaindonesia.com, professor at the Indonesian Education University (UPI) Cecep Darmawan, explained that students' concern during the pandemic period, of course, did not have to care about their classmates. However, concern during the current pandemic is reflected in concern for the surrounding environment.

One of the famous teachings of Ki Hajar Dewantara is "Everyone becomes a teacher, every house becomes a school". Integrating these teachings with current situations and conditions, in terms of character education, of course, is not only a teacher who is responsible for values and moral 
education to students, but it can be interpreted that every family member can teach spiritual, social, knowledge and skills attitudes to children as part of the subject of character education. This condition can also be a momentum to expand the role of parents in guiding the process of education. Therefore, there is a need for collaborative innovation in fostering students between schools, teachers, parents, and students themselves that are ideally interwoven.

In this case, the collaboration between these components can be interpreted by the term Quadruple Helix. Theconcept is helix based on the idea that innovation is an interactive outcome involving many different types of actors. Thismodel helix defines and formalizes the appropriate role for each field in supporting the growth of human resources. Furthermore, the Quadruple Helix concept is a collaboration of four sectors, namely government, business, academics, and civil society which play a role in encouraging the growth of innovation. According to Carayannis and Campbell [2] state the importance of government policies and practices, educational institutions and civil society interacting with each other intelligently, effectively, and efficiently. Thus, the meaning of the Quadruple Helix is adaptation in the educational dimension, namely connecting four major components, namely school committees, teachers, students and parents to build and strengthen character education in the midst of the Covid-19 pandemic, which is called the Tetra Helix. These four factors should work together in an integrated manner, so that they can play their respective roles optimally.

The meaning above gives at least three basic problems faced in education in schools. First, the implementation of education through the implementation of the network makes its effectiveness reduced compared to direct learning. This is caused by various factors such as boredom, lack of interaction in learning, piling up task loads and so on. resulting in an educational crisis in the form of a decrease in the quality of learning quality. Second, learning that is carried out remotely places parents as determinants of the success of learning at home. Parental supervision during remote learning encourages the seriousness of students to take part in learning. Third, in addition to parents, there are important factors that must be considered, namely the independence of students in learning, the readiness of teachers to organize learning, and the great power of the committee/community to provide input and advice on the implementation of policies on education to the government. Currently, these collaborative components are very much needed in the educational crisis situation during the Covid-19 pandemic.

\subsection{Strengthening Character Education}

Sauri [3] states that global phenomena are the most influential factors on the values, character and mentality of a nation, while other factors are internal factors, namely the direction of development in the world of education, namely the development of education based on culture, values and prevailing norms. in the community and subject-oriented (human-oriented development). This means that the direction of the implementation of education based on character education is needed. Character education is a system that instills character values into school members, either in the form of knowledge, awareness or components of the will to implement these values both to God Almighty, oneself, others, the environment, and nationality so that humans become human beings. Kamil[1].

Gafar [4] defines character education as a process of transforming life values to be developed in a person's personality so that they become one in that person's life behavior. Academically, character education is defined as value education, moral education and character education which aims to grow students' ability to make the right decisions and cultivate good morals in everyday life. Samani and Hariyanto [5] say that character education is a process of giving to students to make complete human beings with character in the dimensions of heart, mind, body, and intention. Lickona defines character education as an earnest effort to help a person understand, care about, and act on a core foundation of ethical values.

Furthermore, Arsyad [3] states that character education can also be a hidden curriculum, such as time management, ethics and integrity, thinking skills, willingness to learn, commitment, desire to achieve success/motivation, strong energy drive/very high enthusiasm, verbal communication, creativity, analytical skills, can cope with stress, self and dependent management, problem solving. That way, character education can be interpreted as an effort that is intentionally designed to improve the 
character of students. Therefore, it can be said that character education is an educational system that encourages students to instill character values that involve aspects of knowledge, behavior, awareness or willingness. This is an effort that is designed and implemented systematically related to divinity, oneself, others, and the environment based on religious norms, laws, manners and customs.

\subsection{TheConcept Tetra Helix in Education with thePerspective The Quintuple Helix \\ quadruple helix is the main pillar that plays a} role in encouraging the growth of the creative industry which includes four sectors, namely: government, entrepreneurs, investors, and the community. Theconcept quadruple helix is an extension of the triple helix. According Leydesdorff and Meyer [6], the model of the triple helix is one of the forms of innovation system based on knowledge(knowledge-basedinnovationsystems) that are trying to capture the dynamics of communication and organization by introducing the idea of an exchange of exchanges back and forth(feedback) on the preparation institution.

The information previously presented stated that to create good educational conditions, a set of components that mutually support each other is needed. These elements include the presence of a principal, the presence of teachers and their personalities, as well as students [7]. The basic thing that must be achieved by these elements is that they are positive subjects who have a set of positive characteristics that are able to create comfort and psychological well-being, especially in the learning process [8].

\section{RESEARCH METHODS}

Researchers use approach mix method or also known as mix design. Mixed method means using two approaches, namely the approach approach and the quantitative approach. Method research is a research approach that combines or associates qualitative and quantitative forms. This research approach mix design is dominant and less dominant". The approach dominant in this research is the qualitative approach, while the less dominant approach is the quantitative approach.

Qualitative means something related to the aspect of quality measurement, or the value of meaning contained in a fact or phenomenon. These qualities, values or meanings can only be and are explained linguistically, in language, or in words. Creswell [9] explains that qualitative research is a type of research which relies heavily on information from objects/participants in a broad scope, which is general in nature, data collection is mostly in the form of words or text, and the results are explained and analyzed by words. and events in the study.

The purpose of research based on an approach approach is to be able to understand the object being studied in depth. Komalasari [10] explains that qualitative research is more shaped on processes and meanings that are studied closely, the nature of socially constructed reality, among others by researchers, the pressure of the investigating situation, the burden of values, the way in which social experiences emerge as well as the acquisition of meaning.

The research design uses the parallel convergent method. With this method, researchers collect various types of data at relatively the same time, then they are integrated. Convergent parallel method allows researchers to be able to obtain comprehensive data analysis results. The selection of this method was carried out on the grounds that the data obtained would be more comprehensive because it came from the results of qualitative and quantitative data analysis. What was generated from interviews, observations and documentation was then integrated with the results of the literature review and data from the questionnaire distribution to obtain comprehensive data. Convergent parallel method is one part of the mixed design that is suitable for this research.

\section{RESULTS AND DISCUSSION}

\subsection{Implementation of Character Education: Caring Character}

The educational goals of the Indonesian State are as set forth in the Preamble to the 1945 Constitution which reads "Educating the nation's life" which is then further elaborated through Law No. 20 of 2003 concerning the National Education System Article 3 explains that National education works to develop capabilities and shape the character and civilization of a dignified nation in the context of the intellectual life of the nation. [11]. Then the scope of potential that must be mastered by students was developed to become independent, responsible, and democratic learners [12], so that from some of these potentials it condenses into human values that 
function to improve the quality of education in Indonesia [13]. Human values are embodied in social attitudes at all levels of formal education, both elementary, junior high and high school education. Social attitudes can be observed by using direct observations of students and the social interactions that occur, so in this observation a special study will emerge about the character of social care.

The application of caring character education at SMP Negeri 2 Bandung has its own characteristics, especially in learning activities. This application is implemented in three learning activities including conditioning, exemplary and habituation.

\subsubsection{Conditioning}

The learning planning that is prepared includes preliminary activities, core and closing activities, planning that is prepared through learning so that students can practice various character values including social care [14]. learning and the process of implementing the Learning Implementation Plan (RPP) which includes program activities. Then the stages of preliminary activities, core activities and closing are applied in the implementation of PPKN learning in accordance with the learning method used which contains all social care values that can be applied in the following activities: infaq activities; lending stationery to those who don't have it; can maintain environmental cleanliness; attention to teacher and friend compensation; have a sense of tolerance and able to see. The last section closes with the evaluation used by the teacher with the method specified in the lesson plans. [15] From this series of activities, students are led to increase their concern for others, which is conditioned by the teacher through learning activities.

\subsubsection{Exemplary}

Caring characters certainly don't just come, so the growth of this character must go through various strategies, one of which is exemplary [16]. The example in question is the involvement of the teacher as the person closest to the students, providing various examples of caring for others. According to the results of interviews with teachers at SMP Negeri 2 Bandung, the learning process requires real examples, so that the application of the social aspect is not easy to implement, but requires a consistent example of applying a caring attitude.

\subsubsection{Habituation}

Growing caring characters in the class of students is easy, learning activities and examples do not guarantee that students can implement caring characters. Therefore, we need a mechanism of attitude that is carried out in a directed manner and starts with a habit. This habituation is carried out routinely in order to foster character education, especially character care. Characters that are integrated with daily activities will be easy to melt. The following are habituation activities carried out at SMP Negeri 2 Bandung: Literacy activities (both reading scriptures and reading books; before learning activities to sing the Indonesia Raya anthem; greeting when meeting with school personnel; including $5 \mathrm{~S}$ culture; holding ceremonies with discipline; mutual cooperation activities at school). classroom and school environment on the development of habituation it is consistent with the 21 st century skills needed by students in Indonesia to meet the gold in 2045 with the qualities of character, basic literacy and competence 4 C. [17]

\subsection{Activation of Tetrahelix}

National Educationbasically to develop the skills and forming participants students to prepare students as complete human beings, so that they can develop their potential accompanied by faith and piety to God Almighty. The environment is the main factor forming student character, be it the school environment, family or any kind of community environment. Participants Educate more daily activities in the family environment then also the school environment. Family education and formal education support the success of students to become fully human, in formal activities that require various aspects including:

\subsubsection{Parents}

Biologically, parents pass genes on to their children, so that the behavior of their children will tend to be the same as their parents. However, various factors such as social and cultural factors interfere with the nature of children, so they are not completely the same as their parents, but the family plays an important role in children's education, especially character. Lickona [18] suggests that the family is the main source of moral education for children, so parents are their first teachers in moral education. So education is to be the main role model in caring character. [19]

\subsubsection{Teachers}

Teachers are the spearhead of schools in learning activities. Thus, learning activities are not only teaching, but also educating, with the aim of 
providing achievements not only in academic-based activities but also in non-academic activities. The decisions taken by the teacher in learning activities will have an impact on students, so the experience of the teacher in managing the classroom will determine whether or not learning is effective. The methods and materials to be provided must be mastered so that students will participate in learning activities well.

\subsubsection{Committee}

For the realization of a character-based school, it is necessary to develop democratic and responsible values initiated by the school committee in order to contribute to problems and issues that have an influence on school quality. The role of the community and parents in improving the quality of education in schools is accommodated through an agency called the School Committee. National Education System Law no. 20 of 2003 Article 56 paragraph (3) states that the school/madrasah committee, as an independent institution, is formed and plays a role in improving the quality of services by providing consideration, direction and support for personnel, facilities and infrastructure, as well as education supervision at the education unit level.

\subsubsection{School Officials}

Policies issued by schools will affect the direction of student formation. So, in this case the principal is to make a policy that is in accordance with morals and academics which is then achieved into the vision, mission, and school program. Policies in the form of rules are enforced in a disciplined and effective manner in order to foster a disciplined attitude of students and all school members. Then the school to affix an award in appreciation for showing caring actions towards others [18] has an impact on value-conscious learning that supports student care.

Reflecting on the concept ofinnovation quintuple helix above, it becomes increasingly clear the position of education in the state and society. Education acts as a pro-public innovator and has a sustainable mindset, namely the party who introduces new ideas, methods, and so on. However, it is also pro/supportive of public interests and preserving nature. This means that education produces knowledge, which is the basis of the entire innovation process that serves three interests, namely industry, government, and civil society, as well as from a natural environment perspective. Thus, the success of a student is not only an outcome caused by school factors, but jointly between schools, families and communities.
Thus, success in education is the result of the collaboration of elements in the education system that support each other. In addition, an increase in behavior and burden among elements of education will lead to a better quality of education. Some of the things that make the education system successful are standardization in the teaching and learning process, which focuses on process rather than existence, collaboration between government policies and professional experience, as well as bringing up various educational visions, especially in providing opportunities for children to learn, creativity, and humanity [20]. ] .

\subsection{Collaborative Roles}

ActivationActivation of the tetrahelix is a collaboration of four components that form a system in education that is carried out in schools. Every school must have four main components, namely Parents of Students, Educators, School Committees and School Officials. This collaboration needs coordination so that it gives birth to a policy that can meet the needs of students in learning activities. Berg [21] explained that partnerships between schools, families and communities can produce creative solutions to find out the needs of students, so that their presence can carry a mission to build people and an educational ecosystem that is cultured and characterized by mutual cooperation.

This collaborative effort is carried out in five steps including: 1) Problem Analysis, by conducting diagnostics on the needs of students, educators and the surrounding community, so as to give birth to the main problems that must be resolved; 2) Goal alignment, goals within the school environment in the form of vision, mission and implementation of the mission contained in the school program; 3) Duties and Functions, each element forming a school has its own duties and functions so that to collaborate properly it must be in accordance with the main duties and functions as parents, committees, educators and school officials; 4) Analysis of Supporting Capacity using the quality report cards contained in the school's self-evaluation, every year the school has achievements and records of improvement in each program in eight assessment components; 5) Determination of Character-Based Learning Technical Caring, the implementation of learning activities begins with the sharpening of materials 
and competencies, as well as collaboration for Strengthening Character Education with learning activities.

\section{CONCLUSION}

Basically Strengthening Character Education which reflects the values of social care into three aspects, namely conditioning, exemplary, and habituation. Activation of the role of Tetrahelix, namely parents, teachers, committees and school officials has an impact on value-conscious learning that encourages concern for students. The collaboration of the tetrahelix role is carried out with problems, alignment of goals, affirmation of who does what, carrying capacity, and technical analysis of caring character-based learning.

\section{REFERENCES}

[1] Muslich, M. (2019). Character Education: Answering a Multidimensional Crisis. Earth Literature.

[2] Praswati, AN (2017). The Development of the Helix Model in Increasing Innovation. National Seminar on Management \& Business Research: Development of E-Business Concepts and Research in Indonesia, 690-705.

[3] Suriansyah, A., \& . A. (2015). Principals, Teachers, Parents, and Community Leadership Strategies in Shaping Students' Character. Journal of Cakrawala Pendidikan, 2(2), 234247. https://doi.org/10.21831/cp.v2i2.4828

[4] Kesuma, D. (2012). Character Education Theory and Practice Studies in Schools. Offset Rosdakarya Youth.

[5] Herliandry, LD, Nurhasanah, N., Suban, ME, \& Kuswanto, H. (2020). Lessons Learned During the Covid-19 Pandemic JTP - Journal of Educational Technology, 22(1), 65-70. https://doi.org/10.21009/jtp.v22i1.15286

[6] Qomarudin, M. et al. (2018). The Strategy of Who Wants to Do What in the Development of the Quadruple Helix Model Synergy between the Government, Universities. Development Economics Study Program, Muhammadiyah Palopo College of Economics, Management Study Program, Muhammad College of Economics. 4(2), 13-23.
[7] Agustang, A. (2020). Social Collaboration Model for Character Education in Private Schools in Bissappu District, Banten Regency. Journal of Basic Education: Proceedings of the National Seminar and Discussion on Basic Education

[8] Ramdani, Z., \& Fahmi, I. (2016). Profile of character strength and achievement in students. Psychopaths: Scientific Journal of Psychology, 1(1), 98-108. doi.org/https://doi.org/10.15575/psy.v1 i1.471

[9] Creswell, JW (2008). Research Design, Qualitative, Quantitative, and Mixed Approaches (Third Edition). Bandung: Student Library.

[10] Komalasari. (2014). Contextual learning of concepts and applications. Bandung: Refika Aditama.

[11] National Education System. (2003). Law No.20 of 2003. Ministry of National Education.

[12] Mulyasa, HE (2013). Character Education Management. Jakarta: Earth Literacy.

[13] Busyaeri, A., \& Muharom, M. (2016). The Influence of Teacher Attitudes on Character Development (Social Care) of Students at Mi Madinatunnajah, Cirebon City. Al Ibtida: MI Teacher Education Journal, 2(1).

[14] Rachman and Lestari. 2017. Education and Development of National Character. Semarang. Fasrindo.

[15] Himmah, F., Tukidi., Mulianing, F. (2019). Implementation of Social Care Character Education in SMP Negeri 1 Karangtengah Demak. SOCIAL. 1(2). DOI 10.15294/sociolium.v1i2.36421

[16] Setiawatri, N. Kosasih, A. (2019). Implementation of Social Care Character Education in Pluralism Society in Cigugur Kuningan. Journal of Character Education No 2, https://doi.org/10.21831/jpk.v9i2.22986

[17] Andiarini, SE., Arifin, I., Nurabadi, A. (2018). Implementation of the Character Education Strengthening Program through Habituation Activities in Improving School Quality. JAMP: Journal of Educational Administration and Management. vol. 1 (2), Pages: 238-244

[18] Lickona, T. (2015). Educating to Build Character translated by Juma 
Abdu Wamaungo from the title Educating Character: How Our Schools Can Teach Respect and Responsibility. Jakarta: PT. Bumi Aksara

[19] Abdilah, H. (2019). The Role of Parents and Teachers as Educators in Shaping Children's Character. Mumtz. 3(1), 219-250. DOI: https://doi.org/10.36671/mumtaz.v3i2.42

[20] Sahlberg, P. (2011). Finnish fourth way. Journal of Educational Change. 12, 173-185. doi.org/10.1007/s10833-011-9157-y

[21] Mustadi, A., Zubaidah, E., \& Sumardi, S. (2016). The Role of School Committees in Improving the Quality of Learning in Elementary Schools. Journal of Educational Horizons, 35(3), 312-321. https://doi.org/10.21831/cp.v35i3.10578 